\title{
Key Practices and Interventions for Training and Transitioning UR Students from an HBCU into Advanced Degree Programs in the Biomedical Sciences
}

\author{
James E. Raynor, Jr. ${ }^{*}$, Juliette B. Bell ${ }^{2}$, Sherrice V. Allen ${ }^{1,3}$, Dawayne Whittington ${ }^{4}$, Cathy Bald- \\ win ${ }^{1}$, and Amita Naik'
}

' Department of Biological Sciences, Fayetteville State University, 1200 Murchison Rd, Fayetteville, NC 28301, USA $^{2}{ }^{2}$ University of Maryland Eastern Shore, Princess Anne, MD 21853, USA; ${ }^{3}$ Present Address: SVA1 Consulting, LLC, 321 Sharpsburg Rd, Fayetteville, NC 2831 1, USA; ${ }^{4}$ Strategic Evaluations, Inc., 5501 Woodberry Rd, Durham, NC 27707, USA

Received: May 1, 2014 / Accepted: May 23, 2014

\begin{abstract}
For more than $\mathbf{3 0}$ years, institutions funded by NIH had less than an impressive record for achieving diversity in the biomedical workforce. To address this concern, NIH recently implemented a series of bold initiatives to bridge the gaps in NIH training programs to further promote diversity. However, critical to the success of these initiatives is the timely reporting, from institutions with large diverse populations such as HBCUs, of evidence-based practices, strategies, and interventions for training and transitioning individuals underrepresented (UR) in the biomedical sciences from baccalaureate to Ph.D. degree programs. To this end, the purpose of this study is to evaluate the 10-year success of the NIH-funded MBRS Fayetteville State University (FSU) Research Initiative for Scientific Enhancement (FSU-RISE) program for training and subsequent transitioning of UR students from the baccalaureate degree into advanced degree programs in the biomedical sciences. We hypothesized that the FSU-RISE program would significantly increase the number of well-prepared undergraduate UR biology and chemistry students who would graduate and transition into advanced degree programs in the biomedical sciences. This article provides evidence-based findings on practices, strategies and interventions for preparing UR individuals from a Historically Black College and University (HBCU) for successful entry into Ph.D. programs.

Keywords: NIH, diversity, underrepresented (UR) students, biomedical workforce, MBRS RISE program, evidence-based practices, research-intensive institutions and $\mathrm{HBCU}$.
\end{abstract}

\section{Introduction}

Creating diversity in the biomedical workforce is a major aim of the National Institutes of Health (NIH), the major medical research agency in the nation for the prevention, diagnosis and treatment of human diseases (NRC, 2005). As the citizenship of racial-ethnic groups is projected to significantly increase in the United States (US) by 2050, development of a biomedical workforce, which utilizes the broad participation and research expertise of individuals from all UR groups will be essential for maximizing the nations' research talents and competitive standing in research and development (R\&D) (Denson and Chang, 2009; Page, 2007; Hong, 2004). Over the past three decades, $\mathrm{NIH}$ has allocated billions of dollars towards building a diverse biomedical workforce (Wadman, 2012). However, despite these large financial investments, NIH-funded institutions have not had an impressive record for developing a robust workforce that utilizes the research potential of all U.S. citizenship including women, individuals from UR racial-ethnic groups, individuals with disabilities, and those from disadvantaged backgrounds (Wilder et al., 2013). While previously implemented NIH Diversity Programs were designed to address the shortcomings of the biomedical workforce, the transformative impact of many of these initiatives favored the advancement of individuals from majority groups several folds over those from UR groups. For example, after the doubling of the NIH budget in 1998-2003, a sharp increase was observed in the number of U.S. Ph.D. prepared graduates from majority groups; although, the increased budget was intended to spike opportunities for UR groups to enter in the biomedical workforce. Comparison of national academic success 
rates of UR students with their white counterparts revealed that disparities in representation of UR individuals were found at every academic level beginning with high school through completion of the Ph.D. degree in science or engineering (Kameny et. al., 2014; Ginther et al., 2011). In fact, UR groups represent only $10 \%$ of all the doctoral degrees earned in all science, technology, engineering, and mathematics (STEM) in this country (Bell, 2009). Further, Ginther et al. (2011) reported that African Americans are less likely to publish in their fields, become full professors and obtain NIH ROI funding when compared to their white counterparts (Tabak et al., 2011). As a result of the report of Ginther et al. (2011), NIH organized a distinguished working group to make a series of recommendations to engage college students in activities to enhance retention and interest in research careers, and to provide strategies as well as tools for trainees at all career stages to excel in the biomedical research enterprise. The working group's recommendations led to the proposal of three major courses of action including the development of a National Research Mentoring Network (NRMN); an innovative programs supporting the aim of Building Infrastructure Leading to Diversity (BUILD); and the creation of a new senior scientific position, the Chief Officer for Scientific Workforce Diversity. This person will lead NIH's effort to diversify the biomedical research workforce (NIH, 2012a). Identifying strategies, best practices, and interventions as well as the efficacy of program components for training and subsequent transitioning of UR individuals to the Ph.D. degree are solid approaches for accelerating the development of a more diverse biomedical workforce (McGee et al., 2012; Poodry, CA., 2006). Therefore, institutions with a history of training a large diverse population of students should report successful, evidence-based approaches for transitioning UR individuals from the baccalaureate degree to the Ph.D. degree to inform policy makers and stakeholders of successful initiatives that promote diversity.

Here, we report our findings from a 10 year study of undergraduate training and subsequent transitioning of UR biology and chemistry majors, who participated in the NIH MBRS R-25 Fayetteville State University (FSU) Research Initiative for Scientific Enhancement (FSU-RISE) program (RISE scholars), from baccalaureate degrees into Ph.D. programs at institutions of "lower" and "higher" (research intensive) activity. The three-fold purpose of this study was to: (1) test the hypothesis that the FSU-RISE program would significantly increase the number of well-prepared FSU UR biology and chemistry students who would graduate and transition to advanced degree programs in the biomedical sciences; (2) analyze differences in the profiles of FSU-RISE scholars to identify demographic variables and program components that were most critical for preparing FSU-RISE scholars for competitive entry into biomedical Ph.D. degree programs at institutions classified by Carnegie as "higher research activity" versus "lower research activity;" and (3) present lessons learned from our 10-year study to aid other minority-serving institutions with similar students in the preparation and transitioning of UR students from baccalaureate degree programs into advanced degree programs in the biomedical sciences. This article provides evidence-based findings on practices, strategies and interventions for preparing UR individuals for successful entry into
Ph.D. programs. FSU-RISE program training activities, which also include activities non-RISE scholars may participate, are summarized in Table 1.

\section{Methodology}

Longitudinal data from 2002-2012 collected as part of a mixed-methods evaluation of the RISE program were the basis of this study. These data sources included:

Scholar Demographics from the RISE Internal Records, FSU's Natural Science Department and Institutional Research Office, and iBioSketch.com. - Through application records as well as data from the Registrar's Office, we compiled demographic data on RISE students included in this study. These variables included gender, race/ethnicity, undergraduate major, cumulative GPA, and Graduate Record Examination (GRE) scores. In addition, iBioSketch.com, a proprietary Internet-based tracking tool designed by our external evaluation team and internal project records were used to provide information on the number of intramural/ extramural research experiences and scientific publications that resulted from these experiences.

Questionnaire and Interview Data from Scholars and Research Mentors-Instruments used to assess scholar and research mentor's perceptions of scholars' research training in the RISE program included: (1) Student and Faculty Mentor Surveys; and (2) Focus group interviews. Scholar surveys were administered online near the end of each year of training while mentor surveys were administered electronically to research mentors near the end of the summer research experience to assess their perceptions of scholars' training experiences. Mentor responses were not shared directly with students. Student focus group interviews were held near the end of each academic year. First year cohorts were separated from second and third year cohorts during interviews to assess the impressions of the program from a first year and returning scholar perspective. Scholar surveys were completed online.

Questionnaire Data from non-RISE Scholars-An exit survey administered to graduating seniors at the close of the academic year served as a data source for non-RISE student comparison group. The data set for this study stretches across 100 RISE scholars and 177 non-RISE FSU students who matriculated at FSU during the same time frame.

Internal Records Verified through the National Student Clearinghouse on Advanced Degree Placements -Data collected by RISE project leaders, along with results of queries submitted to the National Students Clearinghouse by the external evaluation team provided the details on students' advanced degree placements.

Carnegie Classifications for Advanced Degree ProgramsInstitutions in which students were pursuing advanced degrees were coded by Carnegie Classification using the website http:// classifications.carnegiefoundation.org/. Institutions in which students were pursuing advanced degrees ranged across six (6) different Carnegie Classes: Master's, Master's Larger, Doctoral, Research (high), Research (very high) and Special Emphasis Medicine. Institutions were then clustered into two categories in terms of research activity, lower and higher. The group labeled 
Table 1. Summary of FSU-RISE Program Training Activities.

\begin{tabular}{|c|c|c|c|}
\hline Activity & Goal & Process & Frequency \\
\hline lentoring & $\begin{array}{l}\text { To nurture the personal, professional and } \\
\text { leadership development of UR students } \\
\text { and to build self-efficacy }\end{array}$ & $\begin{array}{l}\text { Link UR students with faculty/staff who will } \\
\text { provide mentoring }\end{array}$ & $\begin{array}{l}\text { Summers \& } \\
\text { Academic Year }\end{array}$ \\
\hline *Academic Support & $\begin{array}{l}\text { To improve academic performances of UR } \\
\text { students }\end{array}$ & $\begin{array}{l}\text { Provide UR students tutoring and enrichment } \\
\text { materials for gateway courses such as } \\
\text { biology, mathematics, chemistry and physics. }\end{array}$ & Academic Year \\
\hline $\begin{array}{l}\text { *Enrichment } \\
\text { Seminars }\end{array}$ & $\begin{array}{l}\text { To enhance the professional and } \\
\text { leadership development of UR students }\end{array}$ & $\begin{array}{l}\text { Provide UR students a series of workshops on } \\
\text { college survival skills, preparation of personal } \\
\text { statements, applications to summer research } \\
\text { programs or graduate schools and practice } \\
\text { with students on their workshop and } \\
\text { conference presentations. }\end{array}$ & $\begin{array}{l}\text { Mondays, } \\
5: 30-7: 30 \text { PM }\end{array}$ \\
\hline $\begin{array}{l}\text { Biotechniques } \\
\text { Workshops }\end{array}$ & $\begin{array}{l}\text { To build the basic research skills of UR } \\
\text { students }\end{array}$ & $\begin{array}{l}\text { Engage UR students in hands-on workshops } \\
\text { covering the use of instrumentation, media } \\
\text { preparation, cell culturing, and purification, } \\
\text { detection, and manipulation of DNA, RNA, } \\
\text { and proteins. }\end{array}$ & $\begin{array}{l}\text { Saturdays, } \\
9: 00 \text { AM - 1:00 PM }\end{array}$ \\
\hline $\begin{array}{l}\text { *Scientific } \\
\text { Communication } \\
\text { Course }\end{array}$ & $\begin{array}{l}\text { To enhance UR students' technical writing, } \\
\text { and ability to read and comprehend } \\
\text { journal articles }\end{array}$ & $\begin{array}{l}\text { Enroll UR students in Scientific Communication } \\
\text { course ( } 3 \text { credithours) }\end{array}$ & $\begin{array}{l}\text { During first year of } \\
\text { program }\end{array}$ \\
\hline $\begin{array}{l}\text { *Molecular Biology } \\
\text { Course }\end{array}$ & $\begin{array}{l}\text { To enhance UR students' understanding } \\
\text { and appreciation of research tools used } \\
\text { in biomedical research }\end{array}$ & $\begin{array}{l}\text { Enroll UR students in a Molecular Biology } \\
\text { course ( } 3 \text { credithours) }\end{array}$ & $\begin{array}{l}\text { During first year in } \\
\text { program }\end{array}$ \\
\hline *Research Seminars & $\begin{array}{l}\text { To increase awareness, interest and } \\
\text { knowledge of UR students in biomedical } \\
\text { research }\end{array}$ & $\begin{array}{l}\text { Engage UR students in faculty and student } \\
\text { research seminars in the biomedical sciences }\end{array}$ & Monthly \\
\hline $\begin{array}{l}\text { Intramural/Extramur } \\
\text { al Research } \\
\text { Experiences }\end{array}$ & $\begin{array}{l}\text { To provide UR students in meaningful } \\
\text { research experiences in the biomedical } \\
\text { research field and to build self-efficacy }\end{array}$ & $\begin{array}{l}\text { Link URs with faculty research mentors at FSU } \\
\text { and at external research institutions }\end{array}$ & $\begin{array}{l}\text { Summers \& during } \\
\text { Academic Year }\end{array}$ \\
\hline *GRE Preparation & $\begin{array}{l}\text { To enhance the verbal, quantitative, and } \\
\text { analytical writing skills of UR students in } \\
\text { preparation for the GRE exam }\end{array}$ & Engage juniors and seniors in GRE workshops & $\begin{array}{l}\text { Saturdays (8 wks) } \\
9: 00 \mathrm{AM}-1: 00 \mathrm{PM}\end{array}$ \\
\hline $\begin{array}{l}\text { Student Team } \\
\text { Building Activities }\end{array}$ & $\begin{array}{l}\text { To promote team building and leadership } \\
\text { development in UR students and to build } \\
\text { self-efficacy }\end{array}$ & $\begin{array}{l}\text { Engage UR students in group activities for } \\
\text { team building and leadership development }\end{array}$ & Academic Year \\
\hline $\begin{array}{l}\text { Conference } \\
\text { Presentations \& } \\
\text { *Career Trips }\end{array}$ & $\begin{array}{l}\text { To promote the scientific communication of } \\
\text { data, networking, and awareness of } \\
\text { academic programs and careers in } \\
\text { biomedical research }\end{array}$ & $\begin{array}{l}\text { Sponsor trips to colleges and universities } \\
\text { with biomedical programs and to allow UR } \\
\text { students to present their research work at } \\
\text { local, regional, and national scientific } \\
\text { research meetings }\end{array}$ & Academic Year \\
\hline
\end{tabular}

*Participation of RISE and non-RISE scholars. 
as "lower research activity" was made up by institutions categorized as Master's, Master's Larger, and Doctoral institutions. The group labeled as "higher research activity" was constituted by institutions categorized as Research (high), Research (very high) and Special Emphasis -Medical institutions.

Selection of RISE program participants- FSU students are eligible to apply to the RISE program during the second semester of the freshman year. Participants are selected by a competitive application process in which applicants must belong to one of the underrepresented groups (i.e., African Americans, Hispanic Americans, American Indians, and Natives of US Pacific Islands, or people with disabilities); be a citizen or non-citizen national of the United States or permanent resident; be registered fulltime at FSU; have a biology or chemistry major with a minimum 2.8 GPA with at least 30 credit hours of course work; and demonstrate a sincere interest in research and a commitment to completing all aspects of the program through a face-to-face interview with members of the FSU Advisory Committee, which includes at least one senior RISE scholar.

\section{Results}

We compared the graduating GPAs obtained from a senior exit survey of 53 RISE scholars with 118 non-RISE biology and chemistry students to evaluate the impact of the academic support provided to RISE scholars. Data shows that $70 \%$ of non-RISE biology and chemistry students graduated with a GPA of 3.0 or higher. In contrast, $85 \%$ of RISE scholars graduated with GPAs higher than 3.0 (Figure 1.). We also compared which advanced degree programs both RISE and Non-RISE scholars entered upon FSU graduation to determine the impact of the RISE program on transitioning biology and chemistry students into Ph.D. programs. Figure 2 shows a breakdown of the types of degree programs to which students transitioned into following graduation. Data also show that prior to FSU-RISE funding in $2002,71 \%$ of FSU students transitioned from the baccalaureate degree into professional health programs, while 29\% matriculated into Master's degree programs. On the other hand, data from the RISE-era show only $29 \%$ of students matriculating into professional health programs, while $43 \%$ transitioned into Mas- ter's degree programs (up 14\%). In addition, there was a significant increase in students who matriculated directly into Ph.D. programs $(43 \%)$ in comparison to $0 \%$ during pre-RISE area. Table 2. Shows the impact of the FSU-RISE program on RISE scholars, (Biology and Chemistry students) entry into advance degree programs during Pre-RISE and RISE Eras.

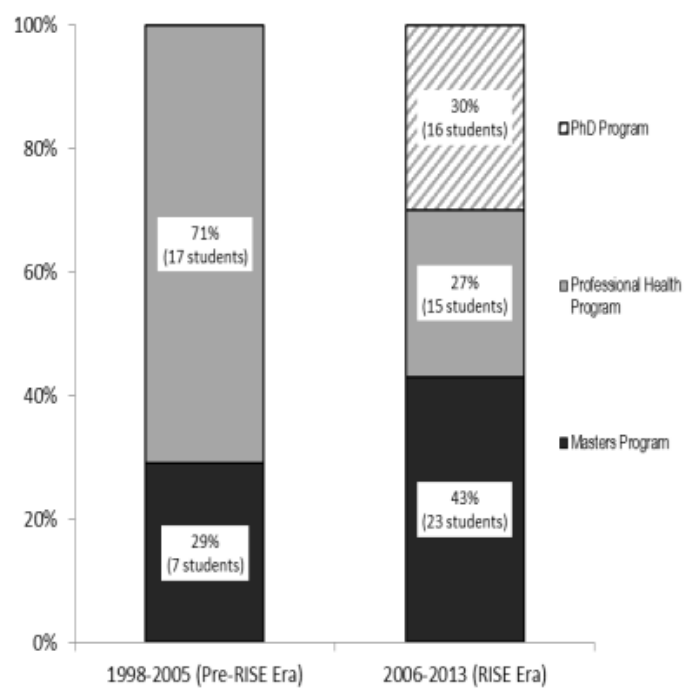

Figure 2. Comparison of natural science students (Biology and Chemistry) who transitioned from the baccalaureate to advanced degrees (master's, professional health, and Ph.D.) during the pre-RISE and RISE eras.

Table 2. Entry of RISE scholars (Biology and Chemistry students) into advance degree programs during Pre-RISE and RISE Eras.

\begin{tabular}{lcc}
\hline Degree Program & $\begin{array}{c}\text { Pre-RISE Era } \\
(\mathbf{1 9 9 8 - 2 0 0 5 )}\end{array}$ & $\begin{array}{c}\text { RISE Era } \\
(\mathbf{2 0 0 6 - 2 0 1 3 )}\end{array}$ \\
\hline Master's & 0 & $16(43 \%)$ \\
Ph.D. & 0 & $16(43 \%)$ \\
Professional & 0 & $5(14 \%)$ \\
Health & & \\
Total & 0 & $37(100 \%)$ \\
\hline
\end{tabular}

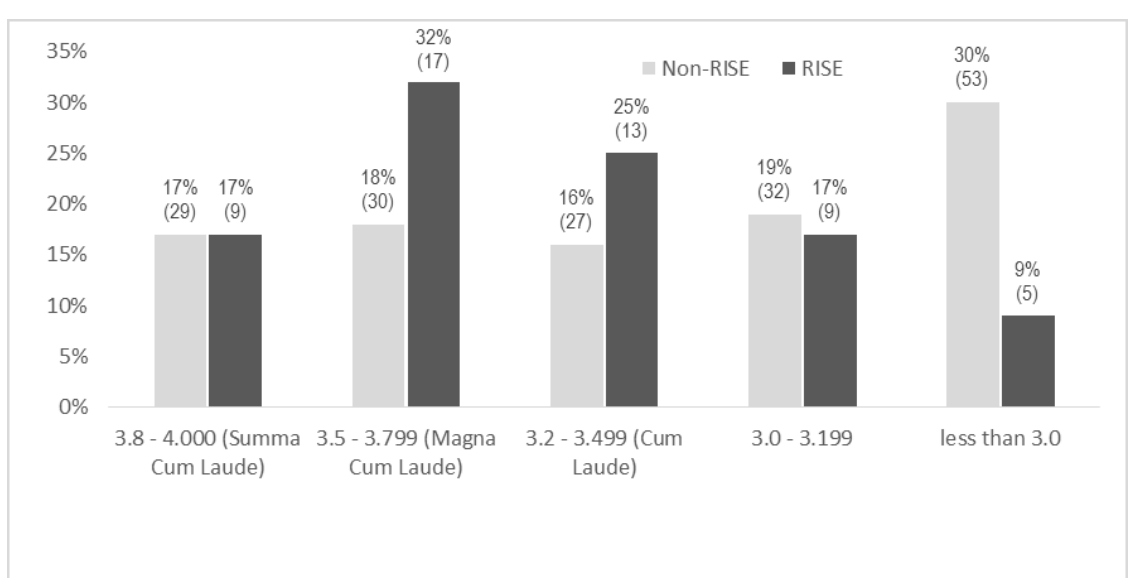

Figure 1. Comparison of graduating GPAs of 53 graduating RISE scholars and 118 nonRISE scholars. 
While a total of 37 FSU-RISE biology and chemistry students transitioned into advanced degree programs during the years evaluated in this study, only the profiles of 27 students, who had a complete data set and accepted into Master's or Ph.D. programs were compared. The remaining ten incomplete (missing GRE scores) student profiles, including five who matriculated into MS programs, two who transitioned into post-baccalaureate programs, and three who transitioned into professional health programs were excluded from the study. The profiles were compared across eight variables: Cumulative GPA, GRE Verbal Percentile, GRE Quantitative Percentile, GRE Writing Percentile, Number of Intramural Research Experiences, Number of Extramural Research Experiences, Total Number of Research Experiences, and Number of Publications as shown in Table 3. Of the 27 profiles analyzed, a total of 11 RISE scholars transitioned into advanced degree programs at institutions classified by Carnegie as being "lower" in research activity, while 16 transitioned to programs classified by Carnegie as having "high research" activity (Carnegie, http://classifications.carnegiefoundation.org/). Data shows that the profiles for students enrolling in degree programs at "high research" activity institutions were generally more competitive applicants for graduate study than those enrolling in institutions with "lower" research activity. Table 3 summarizes profiles of students enrolling in advanced degree programs at low research and research intensive institutions.

Approximately 68 RISE scholars and 27 research mentors completed surveys to assess their perceptions of RISE scholar training and competency in science process skills for graduate school preparation in 11 areas. Results are summarized in Table 4.

Table 3. Profiles for Students Enrolling in Institutions with Lower Research Activity vs. Higher Research Activity.

\begin{tabular}{lcc}
\hline & $\begin{array}{c}\text { Low Research } \\
\text { Carnegie } \\
\text { Classification }\end{array}$ & $\begin{array}{c}\text { High Research } \\
\text { Carnegie } \\
\text { Classification }\end{array}$ \\
\hline Number of RISE Students & 11 & 16 \\
$\%$ Masters / \% PhD & $18 \% / 82 \%$ & $25 \% / 75 \%$ \\
Cumulative GPA & $3.2 \pm 0.3$ & $3.4 \pm 0.3$ \\
GRE_Verbal Percentile & $32^{\text {nd }}$ & $50^{\text {th }}$ \\
GRE_Quantitative Percentile & $25^{\text {th }}$ & $32^{\text {nd }}$ \\
GRE_Writing Percentile & 3.2 & 3.6 \\
\# of Intramural Research & 1.2 & $1.6^{*}$ \\
Experiences & & \\
\# of Extramural Research & 1.6 & 2.0 \\
Experiences & & \\
Total \# of Research Experiences & 2.8 & $3.6^{*}$ \\
\# of Publications & 0.5 & 0.3 \\
\hline *indicates $p<.05$ & &
\end{tabular}

\section{Discussion}

FSU is a comprehensive liberal arts college in North Carolina with a diverse population of students. In 2012-13, the racialethnic make-up of the 6,100 student body was approximately $65 \%$ Blacks, 18\% Whites, 10\% Hispanics, 4.6\% Asians, and $2.2 \%$ Native Americans/Alaskans. While FSU, like most HBCUs, is an excellent resource for students underrepresented in the sciences, many of these students enter college underprepared academically. In fact, of the 661 first-time incoming freshmen from 2012-13,79\% had a SAT score $\leq 1000$; while $70 \%$ had a high school GPA $\leq 3.0$. Additionally, the average four-year graduation rate (2010-12) was $14.7 \%$. Therefore, critical academic interventions are needed to significantly increase the number of UR students in biology and chemistry students who will graduate and transition to graduate schools. To this end, the $\mathrm{NIH}$-funded FSU-RISE program was implemented on the campus of FSU in 2002 with the overarching goal of developing a more competitive applicant pool of UR biology and chemistry students for competitive entry into Ph.D. degree programs in the biomedical sciences. To accomplish this goal, we developed a multifaceted research education program comprised of research training and professional development activities beginning at the sophomore year through FSU graduation/ admissions to an advanced degree program in the biomedical sciences (Table 1) RISE scholars build upon previous knowledge gained as they acquire new knowledge, skills and experiences each year of program participation. Real world research experiences are gained through participation in Biotechniques Workshops and intramural/extramural research experiences. The expected outcome of the RISE program is that $100 \%$ of program participants will graduate with baccalaureate degrees in the sciences and $75 \%$ of the participants will enter advanced degree programs in the biomedical sciences within three years of graduation.

The oldest of four RISE programs in the state of North Carolina, FSU-RISE supported approximately 100 scholars $166 \%$ females and $34 \%$ males) between 2002-2012. The racial-ethnicity distribution of RISE scholars was $84 \%$ African American; 3\% Puerto Rican; 6\% Hispanic; 1\% Mexican; 4\% Asian/Pacific Islander/Indonesian; and $1 \%$ Native American. Approximately $62 \%$ of RISE participants had declared majors in biology at the point they were selected for the program; $24 \%$ had selected chemistry as a major. An additional $5 \%$ had chosen to double major in biology and chemistry. The average GPA of students accepted into the program was 3.3, while the mean GPA for the 67 graduates to date was also 3.3 (Table 3 ) This suggested that academic support provided for RISE trainees enrolled in gateway biology and chemistry courses had a positive impact on scholars maintaining their academic performances while engaging in the enrichment program activities. To date, $67 \mathrm{schol}-$ ars have graduated from the RISE program. Of the 67 graduates, $39(58.2 \%)$ entered advance degree programs after FSU graduation. Eighteen of 39 (46.1\%) entered Ph.D. programs; 16 $(41.0 \%)$ entered Master's programs; 4 (10.2\%) entered doctoral professional health programs, and $1(2.6 \%)$ entered a nursing program. One student currently remains in a post-baccalaureate program with strong likelihood of transitioning into a Ph.D. pro- 


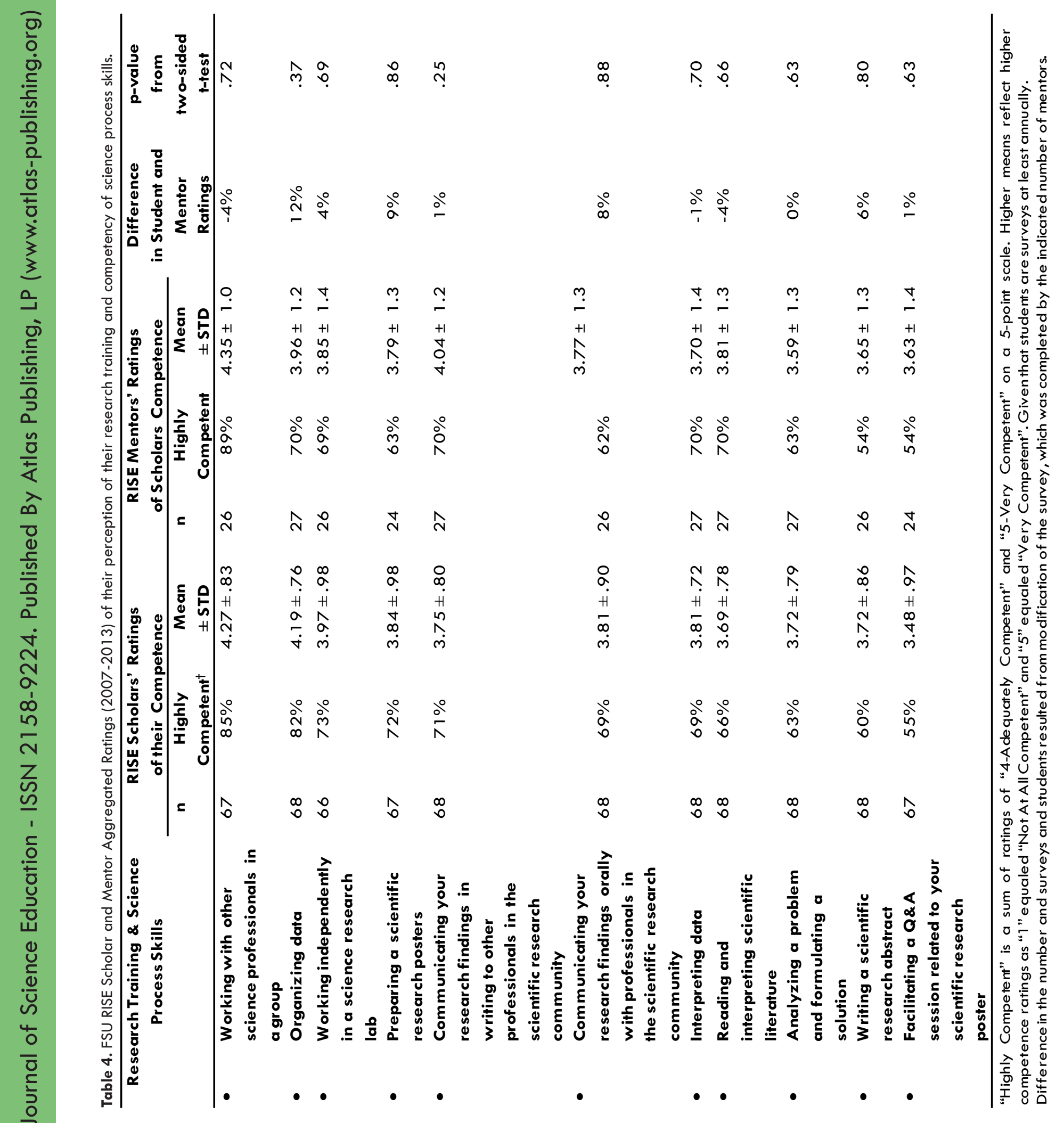


gram given the trend for 3 out of $3(100 \%)$ of the RISE scholars who participated in post-baccalaureate programs eventually transitioned to Ph.D. programs.

In this study, we first explored the effectiveness of the FSURISE program to train/prepare undergraduate UR biology and chemistry majors for Ph.D. programs in the biomedical sciences. To understand the impact the RISE program had on student entry into advanced degree programs, we evaluated a 16-year period (1998-2013), which included a 5-year period prior to the implementation of the RISE program, the Pre-RISE era (19982005), a period when the trend for RISE was being established and RISE area (2006-2013), a period where full implementation of the RISE program was established. Although the FSURISE program was officially implemented in 2002, we wanted to capture the trend for student entry into advance degree programs prior to and after RISE intervention. We observed a positive transformative impact on the number of FSU students in biology and chemistry pursuing advanced degrees, particularly master's and Ph.D. degrees in the biomedical sciences. Comparison of the Pre-RISE era (1998-2005) and RISE era (20062013) revealed a negligible percentage (less than 1\%) of FSU biology and chemistry graduating with baccalaureate degrees and transitioning directly into Ph.D. programs during the PreRISE era (Table 2). Both Pre-RISE and RISE eras encompassed an 8-year period, with three years before and after the PreRISE era to allow time for a trend to be established. During the Pre-RISE era, FSU biology and chemistry students were more likely to transition directly into master's programs. However, during the RISE era, we observed a significant increase from $<1 \%$ to $30 \%$. $\left(X^{2}=12.0, d f=2, p=.002\right)$ in the number of biology and chemistry majors entering directly into Ph.D. programs upon FSU graduation, which is remarkable because this number represents all RISE scholars (Table 2.) This suggested that the intervention of the RISE program had a significant impact on the number of FSU students entering directly into Ph.D. programs during the RISE era. We also explored whether the academic support provided to all RISE scholars made an impact on their overall GPA when compared to non-RISE students. Data shows that RISE students typically graduated with higher GPAs $\left(X^{2}=12.7, d f=6, p=.048\right)$ than their peers during the RISE era (Table 3.). We conclude that the RISE program had both a transformative impact on both overall graduation GPAs of RISE scholars and the number of undergraduate UR biology and chemistry students who directly entered Ph.D. programs in the biomedical sciences after FSU graduation.

A major gap in the educational pipeline for UR students entering biomedical careers exists between UR students earning the baccalaureate degree and subsequent transitioning into the master's degree program (Aud et al., 2010). Therefore, the ultimate goal of the RISE program was to significantly increase the number of prepared undergraduate UR students who will transition directly into biomedical Ph.D. programs. To this end, graduating scholars were required to apply to a minimum of five Ph.D. programs prior to FSU graduation. However, some RISE scholars may opt to also apply to master's programs if they feel their academic performances/profiles were more aligned with these programs only after they have fulfilled the five appli- cations requirement to Ph.D. programs. In addition, RISE scholars were required to update their student accounts periodically with schools they have been accepted in iBioSketch.com, a proprietary Internet-based database for scholars and program leaders to collaboratively store information on participated activities and academic achievements. We utilized information from the database and internal records to establish profiles of RISE scholars accepted into advanced degree programs to explore the types of advanced degree programs RISE scholars were being accepted into as well as factors which were instrumental to their acceptance into the degree programs. To this end, a crosstab of the types of degree programs (master's vs. Ph.D.) revealed that a significantly higher ratio of RISE scholars were accepted into Ph.D. programs in the biomedical sciences at institutions with higher research activity (research intensive) according to the Carnegie classification [Pearson $\mathrm{Chi}=8.429, \mathrm{df}=1, \mathrm{p}=.004$ ] than any other category (Table 3 ). When an ANOVA was run to help determine significant variables that differentiated students who transitioned to institutions "higher" in research activity from those that transitioned to institutions "lower" in activity, results provided support for several practices as strong interventions that can guide the preparation of similar students for competitive entry into Ph.D. programs. The results of the ANOVA show that FSU-RISE scholars who entered graduate programs at institutions "higher" in research activity had significantly more research experiences overall than their peers. This finding confirms earlier research of Pender et al. (2010) that found that research experiences enhance students' competitiveness for being accepted into master's and Ph.D. programs. When total research experience was separated into intramural and extramural experiences, data show that FSU-RISE students who transitioned to graduate programs at institutions "higher" in research activity had significantly more intramural experiences, but statistically the same amount of extramural experience. Studies have shown that receiving research training at research-intensive institutions has several important benefits including significantly improved probability of publishing the research work, timely advanced degree completion, acquisition of tenure positions at researchintensive institutions, and subsequent recipient of an RO1 Awards (Thomas et al., 2007; Gibau et al., 2010; Ginther et al., 2011). However, our data suggested that the combination of intramural research experience with extramural experiences enhanced the competitiveness of scholars looking to enroll in advanced degree programs at institutions "higher" in research activity. One explanation for the significance of the intramural experiences is that these experiences were typically longer in duration, housed on a campus in which students were more familiar, and led by faculty in which students had stronger connections and thereby felt more strongly supported. These factors may have enabled students who participated in more intramural research more time for growth in scientific knowledge and confidence. Quotes illustrating the impact of the length and nurturing environment of some intramural placements follow:

I've been working on my project for about 10 months now, we're looking at a protein, Syntaxin, that's found in the sperm head in the plasma membrane specifically. And after 
localization we're looking to characterize it and see what other proteins interact with it during the acrosome reaction, which is a reaction that sperm undergo before fertilizing an egg. And so we've been able to successfully localize it, we've been able to successfully develop a protocol to see which proteins interact with it during this reaction, so we're excited to do some functional studies so we can get this in print (Student Cohort 2).

[My intramural research mentor] challenges me both professionally and academically and he expects you to do the best, because he sees within you and he doesn't take anything less than that. But in addition to that he's also very nurturing, he cares about what's going on with-- He cares about your academics, he's cares about your education, he wants you to go far, he wants you to succeed in everything that you try to do. And so he makes himself available to help you get-- to help you realize your goals and see them accomplished (Student Cohort 3).

Further comparison of profiles revealed two additional variables (GPA and Verbal GRE) trended toward significance suggesting that they too were strong factors in differentiating students who went to institutions "higher" in research activity from those that transitioned to institutions "lower" in activity. These results support the justification for the inclusion of a strong academic support component, with tutoring and study skills resources built into the program. Additionally, RISE students who transitioned to institutions "higher" in research activity trended higher on their performance on the verbal portion of the GRE. On the other hand, students' performance on the quantitative section of the GRE as well as the extent to which they had co-authored peer-reviewed publications were two variables that did not differ much between the two groups. While longer placements into a research lab often enhances the likelihood of co-authorship of a scientific research publication, our data indicate that strong scientific communication skills, similar to those measured in the verbal section of the GRE, may matter more than a co-authored publication for advancing undergraduates to advanced degree programs at research-intensive institutions. These findings provided support for FSU-RISE activities that focused on strengthening these specific skills, particularly the program's scientific communication course. GRE percentiles across the quantitative, verbal, and writing sections of the exam were on average no higher than the $50^{\text {th }}$ percentile (Table 3 ). However these scores did not appear to heavily impact the competitiveness of applicants for advance degree programs. The results confirm an earlier finding by Morrison and Morrison (1995) that indicated less emphasis may be placed by graduate schools for the use of GRE scores to correlate UR student abilities for future success in graduate school.

Next, to identify other program components and evidencebased practices instrumental to training and transitioning of UR biology and chemistry graduates into Ph.D. programs, we also examined the perceptions of RISE scholars and their research mentors on the knowledge, skills, and experiences scholars received during their training in the RISE program. Research train- ing is essential to preparing students for graduate study and a major training component in the RISE program. Since FSU is a master's granting institution with low activity research activity (http://classifications.carnegiefoundation.org/lookup_listings/ institution.php accessed March 14, 2014), we implemented Biotechniques Workshops for first and second year RISE participants to build their basic research skills in preparation for their intramural and extramural research experiences. RISE scholars participated in extramural research experiences each year of program participation during summers until graduation. They also participated in faculty-mentored research projects at FSU during the entire academic year each year after their first summer research experience. To ensure scholars received at least one summer research experience each summer, scholars were required to apply to a minimum of five summer programs, and subsequently apply to a minimum of five Ph.D. programs in the biomedical sciences at research institutions of their choice during their graduating senior year. Our data show that between 2002-2012, nearly 89 RISE scholars participated in over 192 summer research experiences at more than 75 different research-intensive institutions that stretched across 25 states. When exploring the perceptions that RISE scholars and their research mentors had regarding the scientific knowledge and skills of RISE scholars, we examined student and mentor surveys that were completed at or near the end of the academic year or summer research experience. Analysis of student survey data revealed that students' self-ratings of their research competence across 8 science process skills shows they were most confident in their ability to: 1) work with other science professionals in a group, 2) organize data, and 3) work independently in a science research lab. Mentors' ratings trended highest as they rated RISE students' skills in the same skill set. For example, $89 \%$ of mentors rated their undergraduate RISE trainee as highly competent in their ability to work with other science professionals in a group, while $70 \%$ of research mentors rated their students highly competent in organizing scientific data and communicating this information orally. Table 4. compares the perceptions of scholars and research mentors about scholar training and their competency in science process skills. Statistically, there is a strong alignment of the perceptions of the students' abilities between students and their research mentors. While visually the data may not appear similar, results of the ANOVA shows significant similarities in overall perceptions. The strong alignment in research mentors' and students' ratings across this set of science process skills provides evidence that the Biotechniques Workshops and research training experiences, especially intramural research experiences, have been strong interventions for preparing UR biology and chemistry students for successfully working in extramural laboratories as well as accurately assessing their skills and deficits within the lab environment. Quote illustrating program component strength:

[RISE] helped me with working in small groups because [during] Saturday workshops and working with other science professionals in groups. Because in our workshops, like with the PCR [our mentor] worked with us, he's a professional (Student Cohort 1). 
These data are further supported by the rankings of the usefulness of program components documented through student survey data on how useful they perceived the program activities were in preparing them for competitive entry into a biomedical Ph.D. program. Students were asked to rank the usefulness of program activities as part of the external evaluation team's data collection once a semester. The scale stretches from "1-Not at All Useful" to "5-Very Useful". These ratings have been aggregated to determine what program elements are most useful from the student perspective and grouped by program component. As can be seen in the Table 5., activities that focused on leadership building trended highest in ratings, with $100 \%$ rating the activities in this component highly useful and the activities receiving a 4.7 out of 5 mean rating. This high ranking may be the result of few activities explicitly focusing on this area, leav- ing students to highly appreciate the offerings when they do occur. Training activities ranked second in usefulness with $79 \%$ of students rating the activities in this component highly useful and activities receiving a 4.7 out of 5 mean rating.

Finally, we examined lessons learned from our 10-year evaluation of the FSU-RISE Program. Although there were many lessons to be learned in training UR students from an HBCU for competitive entry into advance degree programs, we identified three major lessons learned in this study. The first and the biggest lesson learned involved the identification of two major points during scholar training where the FSU-RISE program was leaky (ie. scholars were leaving the RISE program). The first critical point we observed high attrition was during Cycle \#1 (4-year funding cycle). In Cycle 1, the FSU-RISE program was awarded 32 training slots, which included support for 8 freshmen, sopho-

Table 5. FSU RISE Scholar and Mentor Aggregated Ratings (2007-2013) of their perception of their research training and competency of science process skills.

\begin{tabular}{|c|c|c|}
\hline Program Components and Interventions & $\begin{array}{l}\text { Mean Usefulness } \\
\text { Rating for } \\
\text { Component } \\
\end{array}$ & $\begin{array}{c}\text { Mean \% Rating the } \\
\text { Program Activities } \\
\text { Highly Useful } \\
\end{array}$ \\
\hline $\begin{array}{l}\text { Leadership Building Activities } \\
\text { - } \quad \text { Leadership Retreat } \\
\text { - } \quad \text { Participation in campus organizations }\end{array}$ & 4.7 & $100 \%$ \\
\hline $\begin{array}{l}\text { Research Training Activities } \\
\text { - } \quad \text { Biotechniques Workshops } \\
\text { - } \quad \text { Intramural/Extramural Research } \\
\text { Experiences } \\
\text { - } \quad \text { Research Presentations from Summer } \\
\text { - Extramural Programs Scholars } \\
\text { Practice Sessions }\end{array}$ & 4.2 & $79 \%$ \\
\hline $\begin{array}{l}\text { Professional Development Activities } \\
\text { - } \quad \text { Conferences (ABRCMS, SNCURCS, etc) } \\
\text { - } \\
\text { - } \\
\text { - } \\
\text { Research Talks } \\
\text { Enrichment Seminars }\end{array}$ & 4.1 & $75 \%$ \\
\hline 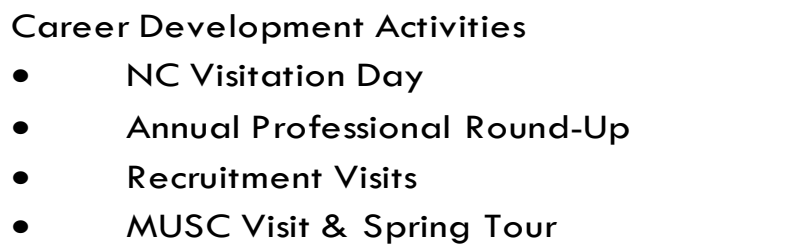 & 3.7 & $68 \%$ \\
\hline $\begin{array}{l}\text { Academic Enrichment Activities } \\
\text { - } \quad \text { Scientific Communications Course } \\
\text { - } \quad \text { Molecular Genetics Course } \\
\text { - } \quad \text { Academic Support (e.g., tutoring and } \\
\text { academic enrichment materials) }\end{array}$ & 3.6 & $53 \%$ \\
\hline
\end{tabular}

"Highly Competent" is a sum of ratings of "4-Adequately Competent" and "5-Very Competent" on a 5-point scale. Higher means reflect higher competence ratings as " 1 " equaled "Not At All Competent" and "5" equaled "Very Competent". Given that students are surveys at least annually, Difference in the number and surveys and students resulted from modification of the survey, which was completed by the indicated number of mentors. 
mores, juniors, and senior scholars. Ten additional training slots were designated for the Pre-RISE program, a summer bridge enrichment program. We found that the student retention rate was nearly $40 \%$ less when first or second semester freshmen students were accepted into the RISE program. This cohort of students were generally characterized as having increased tardiness or absences to program activities, lack of focus or seriousness about program activities, and also having difficulty adjusting to the rigorous structure of the program. Due to these observations, the training slots for the program were reduced during Cycle \#2 to a total of 22 positions, which included 8 sophomores, 8 juniors, and 6 senior students and freshman students were no longer eligible for admission to the RISE program. While similar trends may be observed with first-time sophomore students, overall student retention improved to approximately $85 \%$ when students were accepted into the RISE program as sophomores. Retention of UR students in the biomedical pipeline has been shown to be a global challenge at all levels, especially at the undergraduate to graduate level. In fact, a survey of more than 115 random FSU biology and chemistry students indicated that more than $75 \%$ of students, who were raised in rural counties indicated they never heard of the Ph.D. degree prior to entering FSU. Thus, one of our major challenges related to retention of students in the RISE program is that extra effort is required to "convince" UR students that research careers and the Ph.D. degree can be as rewarding as professional health careers, which students from rural counties have more knowledge about prior to matriculating at FSU (Villarejo et al., 2008). A second critical point where an increased number of scholars were leaving the RISE program during training was observed between the end of the junior and the beginning of the senior academic year at the same time when students were preparing to take or scheduled to take GREs. The majority of scholars leaving the program at this point generally candidly expressed their interest in pursuing other degree programs, mostly professional health programs or they decided to leave the program because of a poor intramu$\mathrm{ral} /$ extramural lab experiences, mainly due to poor relationship or support from the person assigned to be their research mentor (e.g., Principal Investigator (PI), Post-doctoral fellow, or graduate student).

The second lesson learned involves the identification of strategies, which promoted student retention in the RISE program. Previous studies have shown that UR students with low career self-efficacy are more likely to prematurely terminate their pursuit towards science and engineering careers (Betz et al., 1981). While mentoring was implemented on all levels of student training in RISE, as previously mentioned we have also used programmatic modifications as a strategy to increase student retention in the RISE program, especially during the first year of training to address unpreparedness. Interestingly, we learned from students' responses that a more direct student-centered approach is required to help UR students maintain a high-level of interest in science and to believe they can succeed in this career path.

Mentoring was far more effective when it was well-integrated with activities that bolster self-efficacy beliefs, which ultimately enhances career self-efficacy. For example, students stated that they wanted to return to the laboratory of mentors whom they connected well with as well as their research. The trusting relationship makes it conducive for mentors to captivate the interest and commitment of students for the long-haul by vicarious interactions or students being sold by the mentor's verbal persuasions about the science career (Bandura, 1986 and Gibbs et. al., 2013). Similarly, engaging students in team building activities in which they connected well with their peers and program leaders gave students a sense of "belonging" and that they played an important that contributed to the success of the team. Based on our discussions with RISE scholars, positive experiences in the RISE program also made them feel important to the team effort which inspired them to work harder for the success of the team. These included serving as an ambassador or a peer mentor for the RISE program; being accepted to several summer research programs or graduate schools; or bringing home a winning conference presentation award from a local, regional, or national research conference such as the Annual Biomedical Research Conference for Minority Students (ABRCMS).

Ginther et. al. (2009) revealed that UR students experience a delayed transition at every stage of academic milestone which significantly reduces the number of UR students who receive Ph.D. degrees in science and engineering. Several baseline factors have been proposed to elucidate the daunting statistics of racial-ethnic underrepresentation in these fields including socioeconomic background, race-ethnicity, culture, gender, academic preparation and self-concept (Summers et al., 2006). However, no single solution has been reported, thus indicating the problem appears to be multifactorial with variations from one individual to another. On the other hand, studies do show that transition time and persistence towards Ph.D. degrees are significantly improved when theoretically informed interventions are implemented into mentoring activities (Jongyeun et al., 1999; Fletcher, 1990). That is, UR students appear to be more committed to completing Ph.D. degrees when they can correlate their abilities and interests with their career pursuits through mentoring. Thus, developing self-beliefs, which contributes to building career self-efficacy in UR students appear to be equally important for persistence towards careers in the biomedical science field as their development of knowledge, skills, and experiences for these careers (Chemers et al., 2011).

The last major lesson learned from our 10-Year evaluation of the RISE program involves the correlation between research experiences and publications. Originally, we found that RISE scholars were participating in research experiences at sites different from their first extramural research experiences. Very few of these RISE scholars achieved co-authored publications from their summer research experiences. However, when scholars returned to the same research experience during the second summer, scholars were more likely to be included in as a co-author on a publication as well as transition to that institution as a graduate student. We must point out that students who did co-author publications during the first summer research experience conducted their research work at high-intensive research institutions. Again, when ANOVA was run to help determine significant variables that differentiated students who transitioned to institutions "higher" in research activity from those that transitioned to institutions "lower" in activity, having co-authored publications was not 
found to be a significant factor in RISE scholars getting accepted to institutions higher in research activity (Table 3 ). However, it stands to reason that students with co-authored publications are more competitive applicants for graduate study since they show more commitment to the research process and may also be an indicator of commitment to pursuing the Ph.D. degree (Schultz et al., 2011 ).

\section{Conclusion}

$\mathrm{NIH}$ continues to aggressively pursue a more than 30 year quest to achieve greater diversity in the biomedical workforce, which includes a broad representation of US citizens from all backgrounds (Shultz et al., 2011 ). In this study, we examined the 10-year findings of the effectiveness of the NIH-funded FSURISE program, on an HBCU campus, for training and subsequent transitioning UR biology and chemistry students from the baccalaureate degree to advanced degree programs in the biomedical sciences. We compared 27 of 37 profiles of FSU-RISE scholars who successfully entered graduate schools to identify demographic variables and program components that were most critical for preparing FSU-RISE scholars for competitive entry into biomedical graduate programs, particularly Ph.D. degree programs at institutions classified by Carnegie as "higher" research activity (research-intensive) versus "lower" research activity. We identified several strengths of the FSU program, which contributed significantly to the training and transitioning of scholars into advanced degree programs in the biomedical sciences. These included providing (1) academic support for trainees in gateway biology and chemistry courses; (2) a robust research training experiences consisting of Biotechniques Workshops and intramural and extramural research experiences; and (3) links for trainees to engage in research projects and mentoring activities that nurtured their research interests and retained them in the pipeline toward the Ph.D. degrees. Additionally, we found that despite there were few faculty with funded research labs at FSU, RISE scholar participation in intramural research experiences was a significant factor in the successful entry of UR biology and chemistry students into research-intensive institutions at both the master's and Ph.D. levels. When evaluating the RISE program structure, we found two major points in the FSU-RISE training where student retention was the lowest. Retention of UR students were improved upon modification of the program's selection criteria, and the implementation of well-integrated interventions, which promoted self-efficacy and the building of stronger mentor-trainee relationships. Additionally, students trended the usefulness of RISE interventions from highest to lowest for Leadership Building; Research Training; Professional Development; Career Development; and Academic Enrichment. We believe students trended academic enrichment activities the lowest because students utilized there services to varying degrees and some scholars may place less value on this component if this service was not highly utilized for their preparation for competitive entry into Ph.D, programs. Our 10-year evaluation of the FSU-RISE training activities revealed that the program has been successful in promoting undergraduate degree completion and advancing diversity in the biomedical sciences. In fact, a major value of the RISE program is that FSU students now receive the needed training for direct entry into Ph.D. programs from the baccalaureate degree. This was not the case prior to the implementation of the RISE program at FSU. While we faced may challenges with student retention and training given the inherent challenges of preparing UR students for Ph.D. degree programs, we feel extremely comfortable that components of the RISE program as well as the evidence-based interventions presented in this manuscript can be duplicated and broadly used to train and prepare UR students from institutions of similar settings for competitive entry into Ph.D. programs in the biomedical sciences. We concluded from our study that the NIH MBRS FSU-RISE program has significantly increased the number of well-prepared FSU UR biology and chemistry students who graduated from FSU and transitioned from baccalaureate degrees to advanced degree programs, especially Ph.D. programs in the biomedical sciences at research-intensive institutions.

\section{Acknowledgements}

This work was supported by the National Institutes of Health Grant 5R25GM 064508. We thank Dr. Clifton A. Poodry for his comments on the manuscript.

\section{References}

Aud S, MA Fox, RA Kewal (2010) Status and Trends in the Education of Racial and Ethnic Groups. Washington, DC: National Center for Education Statistics; 2010. http://nces.ed.gov/pubs2010/2010015 (accessed 14 March 2014).

The Carnegie Classification of Institutions of Higher Education can be assessed at website: http://classifications.carnegiefoundation.org/

Chemers, MM, EL Zurbriggen, M Syed, BK Goza and S Bearman (2011) The role of Efficacy and Identity in Science Career Commitment Among Underrepresented Minority Students. Journal of Social Issues. 67(3):469-491.

Denson, N and MJ Chang(2009) Racial diversity matters: The impact of diversity-related student engagement and institutional context. American Educational Research Journal, 46(2), 322-353.

Ginther DK, WT Shaffer, J Schnell, B Masimore, F Liu, LL Haak, R Kington (2011) Race, Ethnicity, and NIH Research Rewards. Science 19: 1015-1019.

Hurtado, S (2001) Linking diversity and educational purpose: How diversity affects the classroom environment and student development. In G. Orfield (Ed.), Diversity challenged: Legal crisis and new evidence Cambridge, MA: Harvard Publishing Group, pp. 187-203.

Hurtado, S, CB Newman, MC Tran, and MJ Chang (2010) Improving the rate of success for underrepresented racial minorities in STEM fields: Insights from a national project. New Directions for Institutional Research, 148 (Winter), pp. 5-15.

Institute of Medicine (2002) Unequal Treatment: Confronting Racial and Ethnic Disparities in Health Care. Washington, DC: National Academy. In press.

Jongyeun, $L$ and B Cramond (1999) The positive effects of mentoring economically disadvantaged students. Professional School Counseling 2(3): 172-178.

Morrison T and M Morrison (1995) A meta-analytic assessment of predictive validity of the quantitative and verbal components of the graduate record examination with graduate grade point averages 
representing the criterion of graduate success. Educ Psychol Meads, pp. 55,309-316.

NAS (2011) Expanding Underrepresented Minority Participation. Washington, DC: National Academies. In press.

National Academy of Sciences, National Academy of Engineering and Institute of Medicine (2011) Expanding Underrepresented Minority Participation: America's Science and Technology Talent at the Crossroads, Washington, DC: National Academies www.nap.edu. In press. National Institute of General Medical Sciences (2014). Available at website http://www.nigms.nih.gov/about/budget/Pages/default. aspx

National Institutes of Health (NIH) Biomedical Research Workforce Working Group Report (2012a). http://acd.od.nih.gov/biomedical_research_wgreport.pdf (accessed 15 March 2014).

NIH Biomedical Research Working Group Report. A Working Group of the Advisory Committee to the Director (June 14, 2012). http:// acd.od.nih.gov/biomedical_research_wgreport.pdf (accessed 14 March 2014).

NRC. Assessment of NIIH Minority Research and Training Programs: Phase 3 Washington, DC.: National Research Council (NRC). Committee for the Assessment of NIH Minority Research Training Programs. National Academy of Sciences (2005).

NRC. Assessment of NIH Minority Research and Training Programs. Washington, DC: National Academies 2005a. In press.

NRC. Research Training in the Biomedical, Behavioral and Clinical Sciences. Washington, DC: National Academies 2011 . In press.

Pender M, DE Marcotte, MR Domingo, KI Maton (2010) The STEM Pipeline: The Role of Summer Research Experience in Minority Students'
Ph.D. Aspirations. Education Policy Analysis Archives 18 (30): 1-36. [PubMed: 21841903 ]

Poodry, CA (2006) The Scientific Approach. The Scientist 20 (1 1): s8. Shultz PW, PR Hernandez, A Woodcock, M Estrada, RC Chance, M Aguilar, RT Serpe(2011) Patching the Pipeline: Reducing Educational Disparities in the Sciences through Minority Training Programs. Educational Evaluation and Policy Analysis 33 (1): 95-11 14.

Sources: U.S. Census Bureau; NIH Office of the Director; National Science Foundation Women, Minorities and Persons with Disabilities in Science and Engineering Report. www.nigms.nih.gov/news/reports/ promoteDiversity06072009.htm (accessed 21 May 2013)

Summers, MF and FA Hrabowski III (2006) Preparing minority scientists and engineers. Science 31: 1870-1871.

Tabak, L.A and FS Collins (2011) Weaving a Richer Tapestry in Biomedical Science. Science 333: 940-941 DOI: 10.1126/science. 1211704 .

US Census Bureau. Projected population of the United States, by race and Hispanic origin: 2000 to 2050. http://www.census.gov/ipc/ www/usinterimproj/ (accessed 14 March 2014).

Villarejo $M$, et al (2008) Encouraging Minority Undergraduates to Choose Science Careers: Career Paths Survey Results. CBE Life Sciences Education 7(4): 394-409. [PubMed: 19047426].

Wadman M. NIH tackles major workforce issues. Nature (2012) 492: 167.

Wilder EL, LA Tabak, RI Pettigrew, FS Collins (2013) Biomedical research: strength from diversity. Science 342 (6160): 798. DOI: $10.1126 /$ science.342.6160.798-a. 